Journal of Environmental Science and Public Health

doi: $10.26502 /$ jesph.96120038

Volume 2, Issue 4

fortune

Research Article

\title{
Quality of Vegetables in Central Europe Region
}

\author{
Veronika Rezacova*, Nikola Jancova
}

Brno University of Technology, Brno, Czech Republic

*Corresponding Author: Veronika Rezacova, Institute of Chemistry and Technology of Environmental Protection, Brno University of Technology, Purkynova 118, 61200 Brno, Czech Republic, E-mail: rezacova@fch.vut.cz

Received: 01 November 2018; Accepted: 08 November 2018; Published: 16 November 2018

\begin{abstract}
The quality of vegetables can be assessed by numbers of viewpoints. One of them is the monitoring of the content of hazardous substances included nitrates. High nitrate levels cause methemoglobinemia or blue baby syndrome; a condition found especially including in infants under six months. Most of the nitrates we consume are from either raw or cooked vegetables. Healthy adults may consume fairly large amount of nitrates with few known negative health effects. However, a long-term intake of high amount of nitrates may result into various gastric problems because of the rapid reduction of nitrates to nitrites. Subsequently, the nitrites react with further secondary amines in the stomach which leads to a production of carcinogenic nitrosamines. This work deals with determination of nitrates in vegetables by capillary isotachophoresis. Samples of organic-labeled ("bio") vegetables as well as undistinguished vegetables were purchased in supermarkets and in farmer markets in Brno, Czech Republic. The amount of nitrates contained in the samples differed widely. The lowest content of nitrates was found bellow the limit of quantification. On the other hand only one of the samples exceeded the maximum amount of nitrates allowed by European Union legislation.
\end{abstract}

Keywords: Vegetables; Nitrates; Quality; Isotachophoresis

\section{Introduction}

Vegetables, by definition [1-3] the edible parts of crop plants, are used in gastronomy and as a spice and in phytotherapy as a medicinal herb. Vegetables play the significant role in human nutrition because they are an irreplaceable source of vitamins, minerals, fibers and other nutrients. Sufficient daily consumption of either raw or 
cooked vegetables may aid in prevention of chronic diseases, including cardiovascular diseases, cancers, obesity, osteophoresis and diabetes [4]. It is recommended to consume vegetables and/or fruit at least 5 times per day [5]. Nitrates are an essential component of the bio-environment and participate in the nitrogen cycle found throughout the living nature. Nitrates are reduced to ammonium salts in plants thus enabling the assimilation and production of the amino acids and then proteins. For this reason, fertilizers containing nitrogen are widely used to boost the plant grow speed. However, nitrates tend to be accumulated in plants exposed to unfriendly habitat. Because of the poor conditions the plants may not have enough carbon compounds needed for assimilation of nitrates. Therefore the content of nitrates varies in different crops within a wide range, depending on both climatic and soil conditions during vegetation. Among the main factors affecting the content of nitrates are kind and variety of plan; light and temperature conditions; amount of moisture and fertilization applied. Additionally the time of harvesting, stocking and last but not least kitchen processing plays its role [6-11]. Amount of nitrates occurring in vegetables may range from 1 to $10000 \mathrm{mg} \cdot \mathrm{kg}^{-1}$ [12]. The vegetables are classified into 5 groups by the ability to accumulate nitrates [13], see Table 1.

\begin{tabular}{|l|l|}
\hline Content of nitrates, $\mathbf{~ m g . k g}$ & Vegetable \\
\hline Very low $(<200)$ & $\begin{array}{l}\text { artichoke, asparagus, broad bean, eggplant, garlic, onion, green bean, mushroom, } \\
\text { pea, pepper, potato, summer squash, sweet potato, tomato, watermelon }\end{array}$ \\
\hline Low (200-500) & broccoli, carrot, cauliflower, cucumber, pumpkin, chicory \\
\hline Middle (500-1000) & cabbage, dill, turnip, Savoy cabbage \\
\hline High (1000-2500) & celeriac, Chinese cabbage, endive, fennel, kohlrabi, leek, parsley \\
\hline Very high (>2500) & celery, cress, chervil, lettuce, red beetroot, spinach, rucola \\
\hline
\end{tabular}

Table 1: Classification of vegetables according to content of nitrates.

\subsection{Health aspects}

Nitrates are the compounds of low toxicity and are not dangerous themselves for adults at levels commonly present in ordinary food. Furthermore they tend to be relatively rapidly excreted in the urine or saliva. The acceptable daily intake (ADI) is $3.5 \mathrm{mg}$ of nitrates per $1 \mathrm{~kg}$ of body weight per day. Nevertheless, abundance of nitrates is undesirable in foodstuffs because of rapid reduction of part of nitrates to nitrites by nitrate reducing bacteria in the gastro-intestinal tract. This process may cause foodborne nitrate methemoglobinemia (blue baby syndrome) disease, occurring most in babies fed by artificial nutrition, having 8-10\% mortality. The nitrites react with hemoglobin production methemoglobin, which does not have the ability to carry oxygen. In addition, the baby's blood contains also so-called fetal hemoglobin (hemoglobin F) which is more readily converted to methemoglobin than adult hemoglobin (hemoglobin A). Also, the oxidation-reduction enzyme system catalyzing the back reduction to hemoglobin is in infants less active. The natural level of methemoglobin in the blood does not exceed $1 \%$ of the total hemoglobin. When increasing its content, the clinical form of the disease is manifested by cyanosis and tachycardia. Methemoglobin content above 50\% may be lethal [13-16]. Therefore, the maximum permissible concentration of 
nitrates in drinking water is governed legislatively, for example in $[17,18]$ and it is $15 \mathrm{mg} . \mathrm{L}^{-1}$ for babies and $50 \mathrm{mg} . \mathrm{L}^{-1}$ for adults according to Czech Regulation 252/2004 Coll [18]. Another negative attribute of nitrates is their indirect toxicity after reduction on nitrites which react with amines at stomach acid catalyzed nitrosation. This leads to production of $\mathrm{N}$-nitrosamines, which have been found carcinogenous and have been associated with increased risks of cancer of the stomach, oesophagus and bladder $[13,19]$. This study is focused on the determination and evaluation of amount of nitrates in different kinds of vegetables.

\section{Material and Method}

\subsection{Method}

Nitrates in the different types of the samples can be determined by several analytical methods, namely by spectrophotometry, potentiometry, polarography, chromatography or capillary isotachophoresis [20-24]. Capillary isotachophoresis (cITP) is a nonlinear electrophoretic technique used for selective separation and concentration of ionic analytes. Conventional ITP separations are characteristic by putting the samples between a zone of "fast" leading electrolyte (LE) and a zone of "slow" terminating electrolyte (TE). The analytes of interest have intermediate ionic mobility. After application of a fixed electric current, sample components move forward behind the leading ion and in front of the terminating ion and form discrete adjacent zones according to their electrophoretic mobilities. A completed ITP separation is characterized by a dynamic equilibrium in which all coionic zones migrate at equal velocities. The analytes are identified using the relative step height (RSH) parameter and quantified by the length of the appropriate steps $[25,26]$.

\subsection{Apparatus}

Isotachophoretic analyses were performed using Villa Labeco EA 100 analyzer equipped with a conductivity detector (Villa-LABECO, Slovak Republic). The isotachopherograms were evaluated using the PC software supplied with the analyzer. The samples of $30 \mu \mathrm{L}$ volume were injected by internal sample loop through a sample valve. Leading electrolyte made up of 10 mmol.L $\mathrm{L}^{-1}$ hydrochloric acid (p.a., Penta, Czech Republic), 5.5 mmol.. ${ }^{-1}$ 1,3-bis[tris(hydroxymethyl)methyl-amino]propane (>99\%, Fluka) and $0.1 \%$ hydroxypropylmethylcelulosa (n.a., Aldrich) was used for determination of nitrates. Three terminating electrolytes were tested in electrolyte systems; namely ammonium formate, oxalic acid and citric acid (all p.a., Penta, Czech Republic). All the three systems had good criteria for separation. However, the best response was obtained from the system with above mentioned leading electrolyte and citric acid as terminating electrolyte. Analyses were carried out in a capillary with $0.8 \mathrm{~mm}$ thick and $16 \mathrm{~mm}$ long, with conductometric detection. The current of $250 \mu \mathrm{A}$ was set for 400 seconds in the first step of the analyses. Then $80 \mu \mathrm{A}$ was used until the end of the analyses. The calibration solutions and the samples were analyzed with the above mentioned electrolytes system under these conditions. Calibration curve was built in the range 20-150 mg NO${ }_{3}^{-} \cdot \mathrm{L}^{-1}\left(\mathrm{KNO}_{3}\right.$, p.a., Penta, Czech Republic) using six calibrations standards. Calibration

points were set by measuring the zone length versus standard concentration. The limit of detection (LOD) for determination of nitrates was $18 \mathrm{mg} \cdot \mathrm{kg}^{-1}$ and the limit of quantification (LOQ) was $60 \mathrm{mg} \cdot \mathrm{kg}^{-1}$. 


\subsection{Vegetable samples}

Samples of vegetables including those stated as organic-labeled or "bio-quality" as well as undistinguished were bought in supermarkets and in farmer markets in March 2016 in Brno, the second largest town in Czech Republic, Central Europe (see Figure 1). The following kinds of vegetables were analyzed: beetroot, cabbage lettuce, carrots, cauliflower, celery, iceberg lettuce, kohlrabi, parsley, potato, radishes and white radish. Vegetables were peeled and finely grated. Distilled water was added in order to dilute the vegetables samples ten times. Samples of biovegetables were diluted only twice because of probable lower nitrates content. The samples were extracted for 5 minutes in ultrasonic bath TESLA Teson 4 (Tesla, Czech Republic). Finally, the solutions were filtered and thus got off pieces of vegetables. The obtained solutions were analyzed.

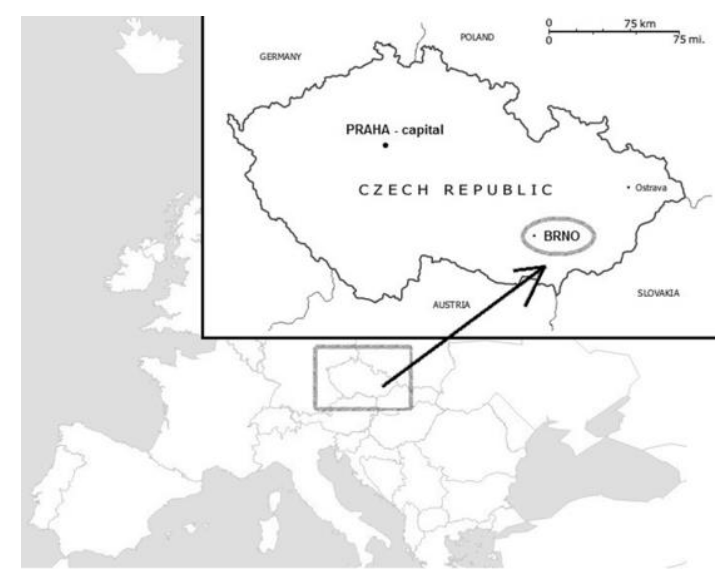

Figure 1: Location map.

\section{Results and Discussion}

Nitrates in various kinds of vegetables were determined by capillary isotachophoresis. The process took approximately 20 minutes. Also, sample preparation prior to analysis took a few minutes. All the samples of vegetables were analyzed and the content of nitrates found in them varied widely from the values bellow limit of quantification $\left(60 \mathrm{mg} \cdot \mathrm{kg}^{-1}\right)$ up to above $7000 \mathrm{mg} \cdot \mathrm{kg}^{-1}$. The results are summarized in the Table 2.

\begin{tabular}{|l|l|l|l|}
\hline \multirow{2}{*}{ Vegetables } & \multicolumn{3}{|l|}{ Content of nitrates, mg.kg-1 $^{-1}$} \\
\cline { 2 - 4 } & Supermarkets & Farmer markets & "Bio" vegetables \\
\hline Beetroot & 534 & - & 313 \\
\hline Cabbage lettuce & 2406 & 7337 & - \\
\hline Carrots & 2952 & - & - \\
\cline { 2 - 5 } & 1261 & - & 215 \\
\hline Cauliflower & $<$ LOQ & - & - \\
\hline Celery & $<$ LOQ & 804 & 155 \\
\hline Iceberg lettuce & $<$ LOQ & - & 284 \\
\hline
\end{tabular}




\begin{tabular}{|l|l|l|l|}
\hline Kohlrabi & 1262 & 938 & $<$ LOQ \\
\hline Parsley & 1511 & - & 462 \\
\cline { 2 - 5 } & 894 & - & - \\
\hline Potato & 661 & 788 & 497 \\
\hline \multirow{2}{*}{ Radishes } & 965 & 2265 & $<$ LOQ \\
\cline { 2 - 5 } & - & 1980 & - \\
\hline White radish & 1875 & - & - \\
\hline
\end{tabular}

Table 2: The content of nitrates in analyzed vegetables, $\mathrm{mg}_{\mathrm{kg}}{ }^{-1}$.

The contents of nitrates bellow limit of quantification were found in five different kinds of vegetables in bio-quality and from supermarkets. These crop-plants were "bio" kohlrabi, "bio" radishes and cauliflower, celery and iceberg lettuce from supermarkets. Those vegetables contained lower nitrates content than it was indicated by P. Santamaria [13]. The highest content, particularly $7337 \mathrm{mg} \cdot \mathrm{kg}^{-1}$ of nitrates, was determined in cabbage lettuce bought on the farmer market. The Regulation of the European Commission sets the maximum levels for nitrates only for spinach and various kinds of lettuces with regard to the time of harvest [27]. The limits values for other kinds of vegetables are usually set by national Regulations of Ministries of Health [28-30]. The content of $7337 \mathrm{mg} \cdot \mathrm{kg}^{-1}$ exceeded the maximum level specified in EU Regulations that is $4500 \mathrm{mg} . \mathrm{kg}^{-1}$ for lettuce harvested from 1 October to 31 March and grown under cover. On this sample of lettuce, small white speckles were visible and could indicate strong fertilization of early forcing and early-ripening lettuce. This cabbage lettuce failed to comply with legislative requirements and should not have been sold. The comparison of the content of nitrates determined in the samples of carrots brings also interesting findings. Carrot is included in set of vegetables that is characterized by lowaccumulation of nitrate, generally $200-500 \mathrm{mg} \cdot \mathrm{kg}^{-1}$ [13]. However, the contents obtained in two samples bought in supermarket were much higher; particularly $1261 \mathrm{mg} \cdot \mathrm{kg}^{-1}$ and $2952 \mathrm{mg} \cdot \mathrm{kg}^{-1}$. These samples came from abroad and failed to comply with the national Regulation which specifies permissible amount $700 \mathrm{mg} \cdot \mathrm{kg}^{-1}$ for root vegetables [28]. These carrots could cause health problems, especially when served to babies. The samples of carrot in bioquality contained $215 \mathrm{mg} \cdot \mathrm{kg}^{-1}$ of nitrates and obeyed Regulation. Similar findings can be observed for the samples of parsley, too. However, in this case the measured values do not vary as much as in the samples of carrot. The amount of nitrates in the analyzed samples of roof vegetables is shown in Figure 2.

In contrast, cauliflower, celery and iceberg lettuce purchased at supermarkets contained the amounts of nitrates lower than limit of quantification and corresponding bio-vegetables. Various kinds of vegetables purchased in supermarkets had completely different quality with respect to content of nitrates. Generally speaking, it was found out that the amount of nitrates in vegetables in bio-quality is lower compared to common vegetables, which is analogous to Gonzalez et al. and Ilic et al. [31, 32]. Such vegetables may be recommended for home food preparation for babies. However, the quality of vegetables from farmer markets was not too good. Nitrates were present generally in higher levels compared with the other samples. This fact may be affected by the season of 
buying the samples when farmers want to harvest in short time and therefore the vegetables are probably too fertilized.

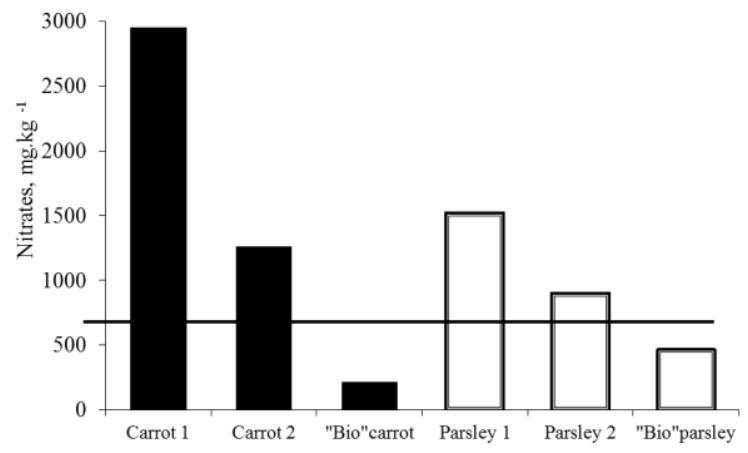

Figure 2: The content of nitrates in roof vegetables, $\mathrm{mg} \cdot \mathrm{kg}^{-1}$.

\section{Conclusion}

It was found out that the amount of nitrates contained in the samples of vegetables differed widely. The lowest content of nitrates was found bellow the limit of quantification. One of the samples-cabbage lettuce-exceeded the maximum level of nitrates allowed by EU legislation. Should the vegetables be used for home preparation of baby food, it is advisable to use vegetables in bio-quality, where amounts of nitrates were found generally lower.

\section{Conflict of Interest}

None

\section{Acknowledgments}

This study was supported by the Grant No. FCH-S-18-5331 from the Ministry of Education, Youth and Sports of the Czech Republic.

\section{References}

1. Vegetable. http://www.thefreedictionary.com/vegetable (2016).

2. Sinha N, Hui YH, Evranuz EO, et al. Handbook of Vegetables and Vegetable Processing. John Wiley and Sons (2010).

3. Vainio H, Bianchini F. Fruits and Vegetables. IARC, Oxford (2003).

4. WHO Healthy diet. http://www.who.int/mediacentre/factsheets/fs394/en/ (2016).

5. WHO. http://www.who.int/dietphysicalactivity/fruit/en/ Promoting fruit and vegetable consumption around the world (2016).

6. Chang AC, Yang TY, Riskowski GL. Ascorbic acid, nitrate, and nitrite concentration relationship to the 24hour light/dark cycle for spinach grown in different conditions. Food Chemistry 138 (2013): 382-388.

7. Watanabe A, Nakane K, Imai K, et al. Localization of Nitrate Anion and Vitamin C in Japanese Radish, and the Effect of Fertilization Method on their Contents. J Jpn Soc Food Sci 60 (2013): 179-183. 
8. Fabek S, Toth N, Redovnikovic IR, et al. The Effect of Nitrogen Fertilization on Nitrate Accumulation, and the Content of Minerals and Glucosinolates in Broccoli Cultivars. Food Technol Biotech 50 (2012): 183191.

9. Liu CW, Sung Y, Chen BC, et al. Effects of Nitrogen Fertilizers on the Growth and Nitrate Content of Lettuce (Lactuca sativa L). Int J Environ Res Public Health 11 (2014): 4427-4440.

10. Poberezny J, Wszelaczynska E, Wichrowska D, et al. Content of nitrates in potato tubers depending on the organic matter, soil fertilizer, cultivation simplifications applied and storage. Chilean J Agric Res 75 (2015): 42-49.

11. Qiu W, Wang Z, Huang C, et al. Nitrate accumulation in leafy vegetables and its relationship with water. J Soil Sci Plant Nutr 14 (2015): 761-768.

12. Prasad S, Chetty AA. Nitrate-N determination in leafy vegetables: Study of the effects of cooking and freezing. Food Chem 106 (2008): 772-780.

13. Santamaria P. Nitrate in vegetables: toxicity, content, intake and EC regulation. J Sci Food Agric 86 (2006): 10-17.

14. Chan TYK. Vegetable-borne nitrate and nitrite and the risk of methaemoglobinaemia. Toxicol Lett 200 (2011): 107-108.

15. Wright RO, Lewander WJ, Woolf AD. Methemoglobinemia: etiology, pharmacology, and clinical management. Ann Emerg Med 34 (1999): 646-656.

16. Martinez A, Sanchez-Valverda F, Gil F, et al. Methemoglobinemia Induced By Vegetable Intake in Infants in Northern Spain. J Pediatr Gastr Nutr 56 (2013): 573-577.

17. U.S. Environmental Protection Agency as the Standard in the Primary Drinking Water Regulations. http://water.epa.gov/drink/contaminants/index.cfm (2016).

18. Regulation No. 252/2004 Coll. of the Ministry of Health of the Czech Republic on determination hygiene requirements for water [in Czech] (2004).

19. Neata G, Stoian E, Mocuta D, et al. Nitrates and nitrites as source of n-nitroso compounds. Roman Biotech Lett 18 (2013): 8583-8586.

20. Sungur S, Atan MM. Determination of nitrate, nitrite and perchlorate anions in meat, milk and their products consumed in Hatay region in Turkey. Food Addit Contam 6 (2013): 6-10.

21. Karovicova J, Kohajdova Z, Lukacova D. Isotachophoretic determination of nitrites and nitrates in vegetable products. Acta Aliment 36 (2007): 7-13.

22. Ito H. New Ways to Evaluate the Quality of Vegetables Using Instruments. Jpn Agric Res Q 48 (2014): 111-120.

23. Kmecl V, Znidarcic D. Accreditation of the analytical method udes for nitrate determination in vegetables. Arch Biolog Sci 67 (2015): 295-302.

24. Liu WY, Wang RB, Chen LK, et al. Simultaneous Determination of Nitrite and Nitrate in Vegetables by Improved Pretreatment Ion Chromatography. J Anal Chem 41 (2014): 1949-1956. 
25. Everaerts FM, Beckers JL, Verheggen Th PEM. Isotachophoresis: Theory, Instrumentation and Application. Elsevier Amsterdam (1976).

26. Markowska A, Stepnowski P. Capillary isotachophoresis for the analysis of ionic liquid entities. J Sep Sci 33 (2010): 1991-1996.

27. Commission Regulation (EC) No. 1881/2006 of 19 December 2006 setting maximum levels for certain contaminants in foodstuffs. Official J EU L 364 (2006): 5-24.

28. Regulation No. 53/2002 Coll. of the Ministry of Health of the Czech Republic on determination of chemical requirements for healthy safety of the food materials [in Czech] (2002).

29. Regulation of 13 January 2003 of the Ministry of Health of the Republic of Poland on maximum levels of pollutants for food area [in Polish] (2003).

30. Regulation No.1/2002 of the Romanian Ministry of Health on security conditions for fresh fruit and vegetables for human consumption [in Romanian] (2002).

31. De Gonzalez MTN, Osburn WN, Hardin MD, et al. Survey of Nitrate and Nitrite Concentrations in Conventional and Organic-Labeled Raw Vegetables at Detail. J T J Food Sci 80 (2015): 942-949.

32. Ilic ZS, Kapoulas N, Sunic L, et al. Heavy Metals and Nitrate Content in Tomato Fruit Grown in Organic and Conventional Production Systems. Polish J Envir Sci 23 (2014): 2027-2032.

Citation: Veronika Rezacova, Nikola Jancova. Quality of Vegetables in Central Europe Region. Journal of Environmental Science and Public Health 2 (2018): 188-195.

This article is an open access article distributed under the terms and conditions of the Creative Commons Attribution (CC-BY) license 4.0 